\title{
Deproteinase Effect of Hydrocolloid Flour Made of "Gembili Tuber" (Dioscorea esculenta L.) on Chemical and Technical Functional Properties
}

\author{
Herlina \\ Agricultural Processing Technology Department, Agricultural Technology Faculty, University of Jember, Indonesia \\ E-mail:linaftp@yahoo.com
}

\begin{abstract}
Hydrocolloid flour extracted of gembili tuber studied in this research to know the chemical and technical functional properties. Hydrocolloid flour extracted directly with distilled water (HFC) and hydrocolloid flour which has reduced protein (deproteinase) by hydrolysis with $\mathbf{0 . 0 5 \%}$ protease of Aspergillus oryzae (HFD). Compared to the chemical properties and technical functional properties covering proximate test, total sugars, solubility, power and emulsion stability, power and foaming stability, water holding capacity (WHC), oil holding capacity (OHC), viscosity to changes in temperature and viscosity to changes in pH. The results showed that different test t-test $(\alpha=0.05)$ moisture content, ash content and fat content between HFC and HFD not significant, while the levels of protein and carbohydrates are significant. Deproteinase the process of hydrocolloid flour made of gembili tuber with $0.05 \%$ protease enzyme use in the extraction able to lower protein content by $49.57 \%$ and increase of carbohydrates by $11.39 \%$. In addition, the process deproteinase effect the technical functional properties of hydrocolloid flour increase solubility, emulsion stability, foam stability, WHC and OHC. Increasing in the temperature by $10-90{ }^{\circ} \mathrm{C}$ lower the viscosity by $70 \%(56.33 \pm 0.19 \mathrm{mp}$ to $17.05 \pm 0.03 \mathrm{mp})$ of HFC and $73 \%(26.16 \pm 1.28 \mathrm{mp}$ to $7,08 \pm 0.79 \mathrm{mp})$ of HFD. The highest viscosity hydrocolloids flour (HFC and HFD) contained at pH 7 and decrease with acidic or alkaline conditions.
\end{abstract}

Keywords — Gembili tuber, hydrocolloid flour, deproteinase, Technical Functional properties

\section{INTRODUCTION}

One of the local resources that have an important role in the structure of society Indonesian food is a gembili (Dioscorea esculenta L.). Gembili is a tuber crops that thrive in various regions in Indonesia. Gembili is an important source of carbohydrates crop after rice, corn and cassava [1]. Until now gembili tuber is still regarded as inferior tubers that utilization is still very limited as boiled or steamed.. Gembili tuber to containing starch and water soluble polysaccharides such as glucomannan.[8],[10]. Processing of semi-finished products is one way of preserving commodity high water content such as various tubers. Technology of flour is one of the alternative process semi-finished products are recommended, as it can be retained, easily mixed (made of composite), nutrient enriched (fortified) and easier to cook according to the demands of modern life who want the very practical [25].

Hydrocolloid Flour of gembili tuber rich glucomannan quite extensive, both in the field of food and non-food. In the field of food hydrocolloid flour of gembili tubers can be used as an ingredient or food additives for various kinds of processed food products, such as noodles or pasta processing will improve the ability to bind water, improve temperature stability, thickener, improved mouthfeel, and reduce the starch solubility on noodles or pasta products. Other functions as a texture improver, stabilizer, foaming agent, gel strenght, gelatin substitute, heat stability, moisture enhancers and others [6].

Hydrocolloid flour of gembili tuber is rich glucomannan in tubers gembili it is a free state or bound with proteins, to improve the content of glucomannan in the extraction process is required deproteinase. Hydrocolloid flour with different purity levels have different characteristics. [13] reported the interaction between manan and soluble proteins in Dioscorea opposita greatly affect the viscosity, the use of a protease enzyme (Aspergillus oryzae ) of $100 \mathrm{U}: 20 \mathrm{ml}$ of the sap Dioscorea opposita to increase its purity will reduce the viscosity of about $70 \%$ in the period 120 minutes. This study aimed to determine the effect deproteinase process against chemical and technical functional properties from hydrocolloid flour of gembili tuber. 


\section{METHODS}

\section{A. Materials and tools}

Raw materials used in this study was obtained gembili tubers from Gintangan Village, District Rogojampi, Banyuwangi. As an adjuvant is protease enzyme of Aspergillus oryzae from Sigma. Chemicals used were distilled water, $\mathrm{H}_{2} \mathrm{SO}_{4}, \mathrm{Na}_{2} \mathrm{SO}_{4}, \mathrm{Na}_{2} \mathrm{~S}_{2} \mathrm{O}_{3}$, Boric acid, $\mathrm{HCl}$, Petroleum Ether, $\mathrm{Na}$ - Phosphate monobasis, $\mathrm{NaOH}, \mathrm{Na}-$ Phosphate dibasis, $97 \%$ ethanol, phenol, Arsenolibdat, $\mathrm{Pb}$ Acetate, and $\mathrm{Na}$ oxalate.

The tools used in this study is a blender (Philips), filter cloth, oven (Selecta), ashing furnace (Muffle), porcelain crucible, eksikator, stopwatch, turning cooler, Analytical Balance Ohaus AP - 310 - O (Switzerland), Thermometer, pH meters Jen - Way -type 3320 (German), Soxhlet apparatus, Prim - Scoman Spectrophotometer (France), Vortex Maxi Max I type 16700, Magnetic Stirrer SM 24, Centrifuge (Yenaco YC -1180 models and the tube), Centrifuge Medifringer, and autoclaving.

\section{B. Extraction hydrocolloid Flour Made of Gembili Tuber}

Extraction hydrocolloids flour made of gembili tuber is done by using distilled water and protease enzymes, the extraction method of HFC, peeled gembili tuber blended with a ratio of ingredients: distilled water $1: 3(\mathrm{w} / \mathrm{v})$ and the obtained slurry tubers. Followed by filtration, the resulting filtrate was centrifuged $4500 \mathrm{rpm}$ for $20 \mathrm{~min}$, the supernatant was precipitated with ethanol obtained 97\% (supernatant: ethanol $=1: 4)$, $\mathrm{HFC}$ clot dried at $50^{\circ} \mathrm{C}$ for 18 hours.

Extraction HFD same extraction method with extraction of HFC, but the results of centrifugation supernatant, the addition protease of Aspergillus oryzae $0.05 \%$, the $\mathrm{pH}$ of the supernatant was regulated $\mathrm{pH} 7.5$ and incubated for $3 \mathrm{~h}$ at $37{ }^{\circ} \mathrm{C}$. Results incubation heated $100^{\circ} \mathrm{C}$ for 10 minutes, centrifuged at $4500 \mathrm{rpm}$ for 20 minutes, the supernatant was precipitated with ethanol obtained $97 \%$ (supernatant: ethanol =1:4), flour wet hydrocolloid obtained was dried at $50^{\circ} \mathrm{C}$ for 18 hours.

\section{Chemical and Technical functional Properties of Hidrocolloid Flour Made of Gembili Tuber}

Chemical properties of hydrocolloids flour of gembili tuber tested include proximate test [2] and total sugars. While technically functional properties tested include solubility, power and stability emulsion [15], the power and foam stability, WHC, OHC [20], and viscosity to temperature and $\mathrm{pH}[3]$.

\section{Data Analysis}

The design study used a completely randomized design (CRD) with five replicates. Chemical properties of the observed data and technical functional properties FHC and FHD do different test $\mathrm{t}$ - test . While technically functional properties displayed in tabular form and to facilitate interpretation of the data then made Graph .

\section{RESULTS AND DISCUSSION}

Proximate Test and Total Sugar on HFC and HFD of hydrocolloid flour made of gembili tuber can be seen in Table I.

TABLE I

Proximate Test, The Total Sugar Content From HFC AND HFD FROM HIDROLOLLOID FLOUR MADE OF GEMBILI TUBER

\begin{tabular}{|l|l|l|}
\hline Parameter Testing & \multicolumn{1}{|c|}{ HFC } & \multicolumn{1}{|c|}{ HFD } \\
\hline Water content $(\%, \mathrm{wb})$ & $11.56 \pm 0.06 \mathrm{~ns}$ & $10.77 \pm 0.25 \mathrm{~ns}$ \\
\hline Ash content $(\% \mathrm{db})$ & $4.75 \pm 0.06 \mathrm{~ns}$ & $5.73 \pm 0.33 \mathrm{~ns}$ \\
\hline Protein content $(\% \mathrm{db})$ & $19.71 \pm 0.07 * *$ & $9.94 \pm 0.04 \quad * *$ \\
\hline Fat Content $(\% \mathrm{db})$ & $1.44 \pm 0.02 \mathrm{~ns}$ & $1.79 \pm 0.15 \mathrm{~ns}$ \\
\hline $\begin{array}{l}\text { Levels of total sugar free } \\
\text { hexoses }(\% \mathrm{db})\end{array}$ & $4.59 \pm 0.16 \mathrm{~ns}$ & $4.21 \pm 0.11 \mathrm{~ns}$ \\
\hline $\begin{array}{l}\text { Levels of total sugar free } \\
\text { pentose and acids uronat } \\
(\% \text { db) }\end{array}$ & $2.27 \pm 0.118 \mathrm{~ns}$ & $3.12 \pm 0.10 \mathrm{~ns}$ \\
\hline $\begin{array}{l}\text { Levels of total sugars after } \\
\text { hydrolysis }(\% \text { db) }\end{array}$ & $72.65 \pm 0.35 * *$ & $78.98 \pm 0.71 * *$ \\
\hline Carbohydrate content $(\%$ db) & $74.10 \pm 0.11 * *$ & $82.54 \pm 0.13 * *$ \\
\hline
\end{tabular}

Table I shows that the different test t-test $(\alpha=0.05)$ moisture content, ash content and fat content between HFC and HFD not significant, while the protein content, total sugars and carbohydrates highly significant. With the use of protease $0.05 \%$ at extractions able to lowered protein content of $49.57 \%$, increase the total sugar content of $8.71 \%$, and $11.39 \%$ carbohydrate content. This is due to the protease is only capable of breaking the bonds between the protein, and protein-bound polysaccharide (glycoprotein) is not split. Proteins and polysaccharides in Dioscorea opposita mucus glycoprotein bound with bonds, so it determines the functional properties [13].

HFC of gembili tuber has a moisture content wb $11.56 \pm$ $0.06 \%$ and $10.77 \pm 0.25 \%$ HFD wb, while HFC ash content $(4.75 \pm 0.06 \% \mathrm{db})$ and HFD $(5.73 \pm 0.03 \% \mathrm{db})$. When compared with commercial gum HFC and HFD ash content greater than gum arabic and xanthan gum but smaller than guar gum. [5] reported that the ash content of commercial gum, the gum arabic, guar gum and Xanthan gum are respectively $1.2 \%, 11.9 \%$ and $1.5 \%$.

\section{A. Technical Functional Properties of hydrocolloid flour Made of Gembili Tuber}

Technical functional properties of Hydrocolloid flour made of gembili tuber (HFC and HFD) can be seen in Table II.

TABLE II

TECHNICAL FUNCTIONAL PROPERTIES OF HFC AND HFD

\begin{tabular}{|l|l|c|}
\hline $\begin{array}{l}\text { Technical Functional } \\
\text { properties }\end{array}$ & HFC & HFD \\
\hline Solubility $(\mathrm{FTU})$ & $215.21 \pm 2.96 * *$ & $156.78 \pm 2.09 * *$ \\
\hline Power Emulsion $\left(\mathrm{m}^{2} / \mathrm{g}\right)$ & $146.37 \pm 0.75 * *$ & $102.17 \pm 0.43 * *$ \\
\hline $\begin{array}{l}\text { Emulsion stability }(\mathrm{min}) \\
60 \text { minutes }\end{array}$ & $338.51 \pm 7.19 * *$ & $362.06 \pm 17.29 * *$ \\
120 minutes & $212.77 \pm 7.79 * *$ & $303.98 \pm 0.08 * *$ \\
\hline Froth power $(\mathrm{ml} / \mathrm{g})$ & $174.40 \pm 2.26 * *$ & $116,80 \pm 2,26 * *$ \\
\hline Froth Stability $(\%)$ & $6.50 \pm 2.12 * *$ & $24.00 \pm 1.40 * *$ \\
\hline WHC $(\%)$ & $1938 \pm 1.33 * *$ & $2050 \pm 5.85 * *$ \\
\hline OHC (\%) & $157.00 \pm 7.26 * *$ & $214.99 \pm 2.56 * *$ \\
\hline
\end{tabular}




\section{B. Solubility of Hydrocolloid Flour Made of Gembili Tuber}

Solubility of hydrocolloids made of gembili tuber expressed with turbidity, hydrocolloid flour remaining in suspension after disentrifusi [12]. Table 2 shows that $(\alpha=$ $0.05)$ HFC and HFD turbidity different significantly, the value of turbidity HFC $(215,21$ FTU \pm 2.96$)$ was lower when compared with HFD $(156,76$ FTU \pm 2.09$)$, this condition HFD showed that higher solubility when compared to HFC. This is due to the protein content of HFC > HFD and content of carbohydrate (polysaccharide) HFC < HFD, a polysaccharide containing glycosyl units, which generally has three hydroxyl groups, where in each hydroxyl group has the possibility of hydrogen bond with one or more water molecules. In addition, the oxygen atoms in the ring and glycosidic oxygen bond linking the sugar ring with other sugars can form hydrogen bonds with water. With each sugar unit in the chain that has a binding capacity of water molecules are large, glycans have a strong affinity to water and hydrated rapidly with the presence of water. In aqueous systems, polysaccharide particles can absorb water, swell and usually experience and perfect partially soluble [24]. Solubility value of Hyacinth Bean protein isolates at $\mathrm{pH} 5.7$ to 6 approximately $60 \%$ [20].

\section{Emulsion Power and Stability of Hydrocolloid Flour Made of Gembili Tuber}

Table II shows that $(\alpha=0.05)$ power and emulsion stability HFC and HFD significantly different, the value of emulsion HFC $(146.37 \pm 0.75 \mathrm{~m} 2 / \mathrm{g})$ was higher when compared to the HFD $(102.17 \pm 0,43 \mathrm{~m} 2 / \mathrm{g})$. This is due to the protein content of HFC > HFD, protein molecules containing hydrophilic and hydrophobic groups that can act as a surfactant compound. Protein molecules adsorbed on the surface of the emulsion system, denatured and unfolded with the amino acid sequence along the surface of the rolls and elongated tail in the second phase, it also increases the ratio of hydrophobic groups that can enhance the emulsion. [11] reported teh protein isolate as emulsifiers preparing a film with a hydrophobic composition will bind tightly to the oil phase, while the hydrophilic part leads to the water phase.

Emulsion stability is calculated on the 60 minute and at minute 120, indicating that the stability of the emulsion HFC $<\mathrm{HFD}$, which at 60 minutes HFC emulsion stability value $=$ $338.51 \pm 7.19$ minutes and HFD $=362.06 \pm 17,29$ minutes, while in the 120 minute emulsion stability value $\mathrm{HFC}=$ $212.77 \pm 7.79$ minutes and HFD $=303.98 \pm 0.08$ minutes. This indicates that the HFD has undergone a process of hydrolysis by the enzyme protease alleged ties between constituent kolekul weakened so much easier dispersed in the emulsion system. Accumulate starch hydrocolloids in emulsion systems (water-oil interface) will increase the protective layer (protecting layer) with mechanical stability and sufficient flexibility then flour hydrocolloid can stabilize water-oil emulsion [17].

Organic matter in this case is a hydrocolloid flour in small concentrations can reduce the surface tension of the solvent in which the decrease in the surface tension of the instability of the emulsion can be minimized [21]. Besides decreasing the surface tension becomes attractive due to its chemical structure capable of uniting two different compounds polarity so as to increase the stability of the emulsion [16].
Emulsion stability of hydrocolloid flour made of gembili tuber (HFC and HFD) is lower than the stability of soy protein isolates $(52.0 \pm 3.8$ hours $)$ [9].

\section{Foam Power and Stability of hydrocolloid Flour of Made Gembili Tuber.}

Table II shows that $(\alpha=0.05)$ the foam power and stability of HFC and HFD different significantly, value foam power of HFC $(174.40 \pm 2.26 \mathrm{ml} / \mathrm{g})$ was higher when compared to the HFD $(116.80 \pm 2.26 \mathrm{ml} / \mathrm{g})$. This is because the use of proteases in HFD decrease the amount of protein that decreases the ability to foam. Rated power foam of hydrocolloids flour made of gembili tuber lower than power foam of protein isolate made of Lablab purpureus L. (232 \pm $12.2 \mathrm{ml} / \mathrm{g}$ ) and is almost equal to isolate proteins from greenpea, grasspea and peachpea with foam power value below $200 \%$ [16].

Foam stability of HFC $(6.5 \pm 2.12 \%)$ was lower when compared with HFD $(24.00 \pm 1.4 \%)$. This is because HFD more dispersed so that bonding foam stabilizer (hydrophobic bonds, hydrogen bonds and electrostatic bonds) are formed more and more and become more stable foam.

\section{E. Water Holding Capacity (WHC) of Hydrocolloid Flour Made of Gembili Tuber}

Table II shows that $(\alpha=0.05)$ Water Holding Capacity HFC and HFD significantly different, the value of WHC of HFC $(1938 \pm 1.33 \%)$ was lower when compared with HFD $(2050.27 \pm 5.85 \%)$. This is due to the sugar component in HFC < HFD and protein components HFC > HFD so hydroxyl groups on HFD > HFC. In addition to the flour hidrikoloid deproteinase process of gembili tuber will break peptide bonds into smaller proteins, this will enhance the hydrophilic group.

WHC values related to the number of hydrophilic polar groups contained in a material. WHC higher value indicates more polar groups in a material. HFC and HFD, WHC values of hydrocolloid flour made of gembili tuber is higher when compared with commercial polysaccharide. WHC of wheat bran $(167 \pm 0.13 \%)$, barley bran $(233 \pm 0.19 \%)$ and Oat bran $(412 \pm 0.23 \%)$ [26]. So that the flour ability to absorb water hydrocolloid greater when compared with commercial gum, so the potential to be applied as a food additive for food products that are specific to the diet.

\section{F. Oil Holding Capacity (OHC) of Hydrocolloid Flour Made of Gembili Tuber}

Table II shows that $(\alpha=0.05)$ OHC of HFC and HFD significantly different, the value of OHC of HFC (113.23 \pm $0.276 \%$ ) was lower when compared with HFD (119.41 \pm $0.552 \%)$. This is due to the presence of deproteinase process using protease and heat denaturation of the protein resulted in HFD. Proteins are denatured to change the composition of space and polypeptide chains, layers of protein molecules in the hydrophobic part turned out hydrophilic folded into will increase the number of hydrophobic groups, this condition will increase the $\mathrm{OHC}$ of a material [4]. Besides hydrocolloid flour will form a tissue matrix that is not compressed because of the low level retrogradation so easily remove water resulting in an increase in the value of $\mathrm{OHC}$ [27]. When compared with the $\mathrm{OHC}$ value of beach pea 
protein isolate (64-82\%), Woodstone pea (90.1 to $94.5 \%$ ) and fild pea (90-127\%). OHC of hydrocolloid flour made of gembili tuber higher, further when compared with the value of $\mathrm{OHC}$ on protein isolates of Hyacinth Bean (254\%), it is lower [20].

\section{G. The Viscosity of Hydrocolloid Flour From Gembili Tuber to Temperature and $\mathrm{pH}$ Effect}

Effect of temperature and $\mathrm{pH}$ against viscosity of hydrocolloid flour made of Gembili Tuber can be seen in Fig. 1 and 2.

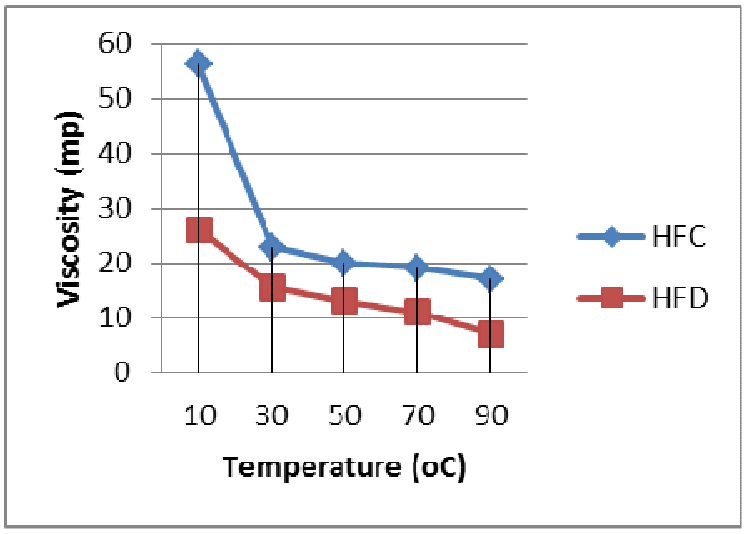

Fig. 1. Effect of Temperature Against Viscosity of hydrocolloid flour made of Gembili Tuber

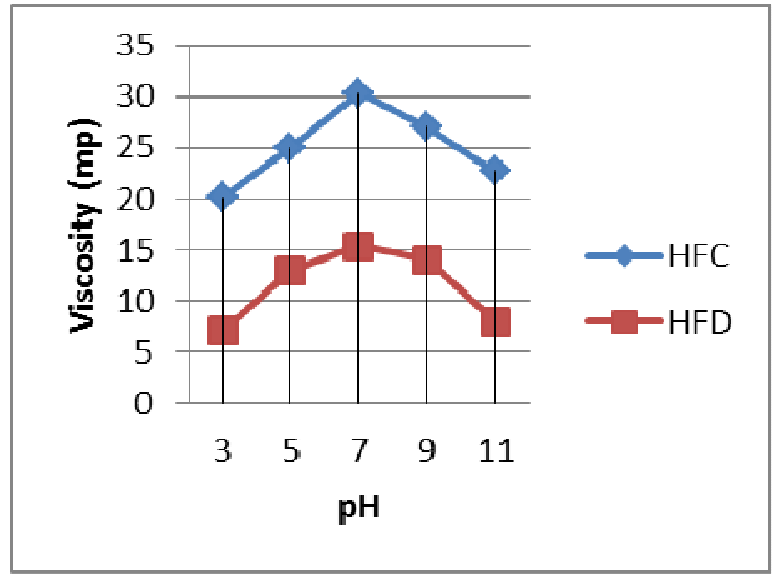

Fig. 2. Effect of $\mathrm{pH}$ Against Viscosity of hydrocolloid flour made of Gembili Tuber

Figure 1. showed that the viscosity of hydrocolloid flour made of gembili tuber $0.5 \%$ decrease with the increase of temperature, in the range of $10-90^{\circ} \mathrm{C}$. This is due to the presence of the polysaccharide molecule warming will have brown motion so that the molecules with each other do not belong together. Viscosity of hydrocolloid flour is determined by the magnitude of many segments of polysaccharides which intersect and interact, in cold conditions hydrocolloid flour molecular motion becomes slower and more segments interacting polysaccharides and fused so that the higher viscosity [14]. Increasing the temperature of $10-90^{\circ} \mathrm{C}$ followed viscosity reduction of HFC by $56.33 \pm 0.19 \mathrm{mp}$ to $17.05 \pm 0.03 \mathrm{mp}$ and HFD by $26.16 \pm 1.28 \mathrm{mp}$ to $7.08 \pm 0.79 \mathrm{mp}$. In this study, an increase in temperature of $10-90^{\circ} \mathrm{C}$ can cause a decrease in HFC viscosity by $70 \%$ and $73 \%$ of HFD. Research conducted by Singh [18] and [19] also reported that the viscosity of the solution of hydrated gum full of seeds Ipomea turpetum and Ipomea campanulata viscosity decreased with increasing temperature. Viscosity $0.5 \%$ alginic acid at room temperature $\left(38^{\circ} \mathrm{C}\right)$ of $10.47 \mathrm{mp}$. Solution viscosity $(0.1 \%)$ durian seed latex by $65 \mathrm{mp}$, Ipomea turpethum $(3.2 \mathrm{mp})$, Ipomea campanulata $(4.5 \mathrm{mp})$, locus bean quality / technical specifications (500-1000 mp) and guar seed quality high (3000-5000 mp) [3], [18], [22]. [7] reported that a $2 \%$ solution of gum tamarind seeds (Tamarindus indica L.) at room temperature has a viscosity of 17-25 mp and will decrease with warming. This value is smaller when compared with HFC and HFD viscosity of hydrocolloid flour made of gembili tuber which has a viscosity at room temperature $\left(30^{\circ} \mathrm{C}\right)$ are respectively 22.89 $\pm 1.49 \mathrm{mp}$ and $15.49 \pm 0.14 \mathrm{mp}$. The viscosity of hydrocolloid flour fully hydrated known to experience diversity directly with various $\mathrm{pH}$ changes occurs in the range ( $\mathrm{pH} 3-11$ ) (Figure 2). The highest viscosity of a $0.5 \%$ solution of HFC and HFD are at neutral $\mathrm{pH}(\mathrm{pH} 7)$ that is equal to $30.31 \pm 0,69 \mathrm{mp}$ in $\mathrm{HFC}$ and at $15,37 \pm 0,29 \mathrm{mp}$ in HFD. Figure 2 shows that the viscosity of the HFC and HFD decreased in acidic or alkaline conditions. The decline in the value of the viscosity significantly visible at $\mathrm{pH} 3$ and 11 respectively for the HFC $(\mathrm{pH} 3=20.10 \pm 0,11 \mathrm{mp}$ and $\mathrm{pH}$ $11=22.67 \pm 0.49 \mathrm{mp})$ and for HFD $(\mathrm{pH} 3=7.00 \pm 0.58 \mathrm{mp}$ and $\mathrm{pH} 11=8.00 \pm 0.29 \mathrm{mp}$ ). The decline in the value of the viscosity at acidic conditions due to the denaturation of the protein that forms a complex with the hydrocolloid flour, causing precipitation in solution. Precipitation occurred at the isoelectric point of the protein in the range of 4 to 4.5 . In addition to the carboxyl group $(\mathrm{COOH})$ in hydrocolloid flour molecules causes easily degraded by a change in $\mathrm{pH}$ which is quite extreme, either acidic or alkaline conditions. According to [23] galaktomanan decreased viscosity at low and high $\mathrm{pH}$. Additionally, [22] reported the $1 \%$ solution of guar gum decreased viscosity above and below $\mathrm{pH} 7$. Overall, the gum solution is known proven very stable at $\mathrm{pH}$ range is quite broad $\mathrm{pH}$ (2.0 to 10.0).

\section{CONCLUSIONS}

Deproteinase with protease enzymes of Aspergillus orizae $0.05 \%$ lower the protein content of hydrocolloid flour of gembili tuber by $\pm 49.57 \%$ and increases the sugar conten by \pm 8.71 . HFC and HFD have different chemical characteristics and technical functional properties.

\section{ACKNOWLEDGMENT}

Thanks go to DP3M that has funded this research, this research may be able to provide for the community.

\section{REFERENCES}

[1] (2008) Gembili. http://www.plantamor.com/index

[2] AOAC, Official Method of Analysis $15^{\text {th }}$, Ed. Association of Official Analytical Chemist, Washington, 1997.

[3] A.M. Amin,.., A.S. Ahmad, Y.Y. Yin, N. Yahya, and N. Ibrahim, Extraction, Purification and Characterization of Durian (Durio zibethinus) Seed Gum. Food Hydrocolloids 21:273-279, 2007.

[4] J.L. Boye, C.Y Ma and V.R. Harwalkar, Thermal Denaturasi and Coagulation of Proteins In: Food Proteins and Their Applications by 
Damodaran, S. and A. Paraf (ed).Marcel Dekker, Inc. New York, 1997.

[5] W.'Cui and G. Mazza, Physicochemycal Chracteristics of Flaxseed Gum. Food Research International, 29: 397-402, 2006.

[6] M. Gaidamashvili, M., Ohizumi, Y., Lijima, S., Takayama, T., Ogawa,T., and K., Characteristik of The Yam Tuber Storage Protein From Dioscorea batatas Exibiting Unique Lectin Activities, J. Biol. Chem, 279, 26028-26035, 2004.

[7] M, Glicksman, Food Hydrocolloids, Academic Press, Inc. USA. p. 6-12, 1982.

[8] Herlina, Eksplorasi Polisakarida Larut Air dari Umbi Gembili. Lembaga Penelitian Universitas Jember, 2010.

[9] S. Damodaran, Food Protein And Their Aplication, Marcel Deeker Inc. New York., 1997.

[10] W.C. Hou, M.H. Lee, H.J. Chen, W.L. Liang, C.H. Han, Y.W. Liu, Y.W., and Y.H. Lin, Antioxidant Activities of Dioscorin, The Storage Protein of Yam ( Dioscorea batatas Decn) Tuber, J. Agric Food Chem, 49, 4956-4960, 2001.

[11] F.L. Hsu, Y.H. Lin, M.H. Lee, C.L. Lin and W.C. How, Both Discorin, The Tuber Storage Protein of Yam (Dioscorea alata cv. Tainong), and its Peptic Hidrolysates Exhibited Angiotensin Converting Enzyme Inhibitory Activities. J. Agric. Food Chem. 50 : 6109-6113, 2002.

[12] R.H. Matthews, Legumes : Chemistry, Technology and Human Nutrition. Marcel Dekker Inc. New York, 1989.

[13] T. Myoda, Y. Matsuda, T. Suzuki, T. Natagawa, T. Nagai and T. Nagashima, Identification of Soluble proteins and Interaction With Mannan In Mucilage of Dioscorea opposita Thunb. Chinese Yam Tuber). Food Sci. Technol. Res. 12(4): 299-302, 2006.

[14] E. Onsoyen, Alginates. In A. Imeson (ed). Thickening and Gelling Agents For Food. $2^{\text {nd }}$. Aspen Publisher Inc. Gaithersburg. Maryland. p. 22-44, 1999.

[15] J.K. Parkington, Y.L. Xiong, S.P. Blanchard, S. Xiong, B. Wang, S Srinivan, and G.W. Froning, Food Chemistry and Technology:
Chemical and Functional Properties of Oxidatively Modified Beef Heard Surimi Stored at $2^{\circ}$ C, Food Sci. , 65(3): 428-433, 2000.

[16] W.J. Peumans and E.J. Van Damme, Lectin as plant defense proteins. Plant physiol. 109: 52-347, 1995.

[17] A.J. Sjoblom, Emulsion and Emulsion Stability. Marcel Dekker. New York. 234 p, 1996.

[18] V. Singh, A. Srivastava, M. Pandey, R. Sethi, and R. Shanghi, Ipomea turpetum seeds : A Potential Source of Commercial Gum. Carbohydrate Polymers 51: 357-359, 2002.

[19] V. Singh, A. Srivastava, M. Pandey, and R. Sethi, A Non Ionic Water-soluble Seed Gum From Ipomea campanulata. Carbohydrate Polymers 74: 40-44, 2003.

[20] A. Subagio, Characterization of Hyacinth beans (Lablab purpureus (L.) Sweet) Seeds From Indonesia and Its Protein Isolate". Food Chemistry $95:$ 65-70, 2006.

[21] Sumingkrat, Kestabilan Emulsi Pestisida Bentuk Emulsifier Concentrate. Balai Besar Penelitian dan Pengembangan Industri Kimia, Departemen Perindustrian dan Perdagangan. Jakarta, 1992.

[22] W.C. Wielinga, Galactomannans. In G.O. Phillips, \& P.A. William (Eds). Handbook of Hydrocolloids. Woodhead Publishing Limited, USA, 2000.

[23] P.A. William and G.O. Phillips, Introduction to Food Hydrocolloids. Handbook of Hydrocolloids. Woodhead Publishing Limited. USA 2000 .

[24] R.L. Whistler and J.N. BeMiller, Food Chemistry. Third edition by Owen R. Fennema. University of Wisconsin \& Madison. Wisconsin. Maral Dekker. New York. p. 178-1911996.

[25] S. Widowati, Tepung Aneka Umbi Sebuah Solusi Ketahanan Pangan. Sinar Tani No. 3302 Tahun XXXIX, 2009.

[26] P.J. Wood, Physicochemical Characteristics and Physiological Properties of Oat (1-3), (1-4) - - -D-Glukan, Oat Bran (P.J.Wood,ed.). Am.Assoc. Cereal Chem. St.Paul, MN.p 83, 1993.

[27] J.F. Zayas, Functionality of Protein In Food. Berlin. Springer, 1997. 